\title{
ACUTE LIVER FAILURE AND SELF-MEDICATION
}

\author{
Falência hepática aguda e automedicação
}

André Vitorio Câmara de OLIVEIRA, Frederico Theobaldo Ramos ROCHA, Sílvio Romero de Oliveira ABREU

From the Centro Universitário Cesmac (Cesmac University Center), Maceió, AL, Brazil.

HEADINGS - Health education. Druginduced liver injury. Hepatic insufficiency. Non-prescription drugs.
ABSTRACT - Introduction: Not responsible self-medication refers to drug use in high doses without rational indication and often associated with alcohol abuse. It can lead to liver damage and drug interactions, and may cause liver failure. Aim: To warn about how the practice of self-medication can be responsible for acute liver failure. Method - Were used the Medline via PubMed, Cochrane Library, SciELO and Lilacs, and additional information on institutional sites of interest crossing the headings acute liver failure [tiab] AND acetaminophen [tiab]; selfmedication [tiab] AND acetaminophen [tiab]; acute liver failure [tiab] AND dietary supplements [tiab]; self-medication [tiab] AND liver failure [tiab] and self-medication [tiab] AND green tea [tiab]. In Lilacs and SciELO used the descriptor self medication in Portuguese and Spanish. From total surveyed were selected 27 articles and five sites specifically related to the purpose of this review. Conclusions - Legislation and supervision disabled and information inaccessible to people, favors the emergence of cases of liver failure drug in many countries. In the list of released drugs that deserve more attention and care, are some herbal medicines used for the purpose of weight loss, and acetaminophen. It is recommended that institutes of health intensify supervision and better orient their populations on drug seemingly harmless, limiting the sale of products or requiring a prescription for release them.

\section{Correspondence:}

André Vitorio Câmara de Oliveira

E-mail: andrecirurgia@gmail.com

Financial source: none

Conflicts of interest: none

Received for publication: 16/01/2014 Accepted for publication: 08/05/2014

DESCRTORES - Educação em saúde. Doença hepática induzida por drogas. Insuficiência hepática. Medicamentos sem prescrição.
RESUMO - Introdução: Automedicação não responsável refere-se ao uso de medicamentos em altas doses, sem parâmetros racionais e associada frequentemente ao álcool. Ela pode levar à interações medicamentosas danosas ao fígado, podendo causar falência hepática. Objetivo: Alertar sobre o quanto a prática da automedicação não responsável pode levar falência hepática aguda. Método: Foram utilizadas as bases Medline via PubMed, Cochrane Library, SciELO e Lilacs, e informações adicionais em sites institucionais de interesse cruzando os descritores acute liver failure[tiab] AND acetaminophen[tiab]; self-medication[tiab] AND acetaminophen[tiab]; acute liver failure[tiab] AND dietary supplements[tiab]; selfmedication[tiab] AND liver failure[tiab]; e self-medication[tiab] AND green tea[tiab]. Na Lilacs e SciELO utilizou-se o descritor automedicação em português e espanhol. Do total pesquisado selecionou-se 27 artigos e cinco sites relacionados especificamente ao objetivo desta revisão. Conclusões - Legislação e fiscalização deficientes e informações pouco acessíveis à população favorecem ao aparecimento de casos de falência hepática medicamentosa em diversos países. $\mathrm{Na}$ lista de medicamentos liberados que merecem maior atenção e cuidado, encontraramse alguns fitoterápicos utilizados com o objetivo de emagrecer, e o analgésico paracetamol. Recomenda-se que organismos nacionais de farmacovigilância intensifiquem a fiscalização e melhor orientem suas populações no consumo de medicamentos aparentemente inofensivos, limitando a sua venda produtos ou exigindo receita médica para liberação.

INTRODUCTION

$\mathrm{S}$ elf-medication is understood as the selection and use of medicines for health maintenance and treatment of symptoms without a prescription, medical guidance or monitoring ${ }^{19}$. This is a practice that occurred and occurs in most countries and civilizations since antiquity. In the Ebers papyrus, written around 2000-1500 BC in ancient Egypt, there are about 900 codes of various remedies from plants, animals and minerals that people used at that time ${ }^{16}$.

Irresponsible self-medication refers to drug use in high doses, without rational parameters, or even at the recommended doses, but associated with alcohol or multiple medications without medical supervision ${ }^{20}$. This leads to drug interactions that are potentially fatal to the liver, possibly causing liver failure and the need for a transplant ${ }^{15}$. Liver transplantation is, in most cases, the only treatment which offers improved survival ${ }^{9}$.

Acute liver failure (ALF) is described as a syndrome characterized by the rapid development of liver damage, decreased hepatic metabolizing of enzymes and drugs, and clinically by encephalopathy and coagulopathy. Historically, the various types of viral hepatitis are among the most common causes in developing countries, while drug intoxication predominates in the USA and Europe ${ }^{15}$.

Self-medication is generally practiced with over-the-counter medicines (OTC), drugs that are released for sale without a prescription, in general are analgesics, antipyretics, non-steroidal anti-inflammatory drugs, decongestants, laxatives and antiemetics ${ }^{6,12,25,28}$. In addition to these, phytotherapics, plant-based remedies, are 
also sold and used freely ${ }^{6,11,12,25,28}$. Deserving attention as potentially hepatotoxic are the painkiller, acetaminophen (also known as paracetamol), and the herbal remedies Kava, Aloe vera, Pennyroyal and Camellia sinensis ${ }^{7,11,13,14,17,18}$.

The World Health Organization (WHO) supports countries by way of ensuring equitable access to safe and effective essential drugs, and through promoting their rational prescription and use ${ }^{20}$. However, in many countries, particularly those in the process of development and with conditions of poverty, legislation and law enforcement are weak, or simply do not exist, and many deaths due to medication causing ALF may be occurring without the proper notification and clarification of the case ${ }^{25}$.

Larson et al. showed that acetaminophen was responsible for $42 \%$ of all cases of ALF in the USA ${ }^{14}$. The use of this medicine by the elderly, alcoholics and those taking overdoses with suicidal intent would be situations considered high risk for the precipitation of $A_{L F}^{7,22,23}$.

The indiscriminate use of herbal medicines with a false idea that they are harmless, or with an obsessive desire to lose weight, because of consumer ingenuity or misleading advertisements, would complement other motivations that have led many people to serious liver injury ${ }^{11,13,17,18}$.

The aim of this review is to warn about how the practice of irresponsible self-medication may lead to ALF, and may result in liver transplant or death.

METHOD

Search services were used from Medline (via PubMed), Cochrane Library, Lilacs and SciELO. The following parameters were studied: acute liver failure AND acetaminophen (293 articles); self-medication AND acetaminophen (14 articles); acute liver failure AND dietary supplements (10 articles); self-medication AND liver failure ( 3 articles); and selfmedication AND green tea ( 2 articles). All searches used filters for humans, and randomized clinical trials and systematic reviews were applied. For Lilacs and SciELO, the search words "automedicação" and "automedicación" were used, applying the filter title words, which resulted in 117 and 44 articles, respectively.

Of the articles researched using the above search headings, and which had a greater impact, were selected: a systematic review of two prospective cohort studies, one being multicenter; five cross-sectional studies; two retrospective; nine case reports; and six expert commentaries. Was sought further data on institutional sites of interest such as the World Health Organization (WHO), US Food and Drug Administration (FDA), National Health Surveillance Agency (ANVISA), Oswaldo Cruz Foundation (Fiocruz) and Argentinian Pharmaceutical Confederation (COFA).

\section{RESULTS}

\section{The current state of self-medication}

There is currently an interesting international debate on self-medication $12,19,25,28,29$. Proponents of the practice argue that self-medication can be safe with some restricted drugs if patients receive correct information by trained pharmacists in pharmacies who guide them properly. Opponents argue that it would be like letting the passengers of a plane take command of the flight while the pilots rest. Patients would self-diagnose based on symptoms only, without taking into account other nuances that doctors utilize, such as physical examination and results of laboratory tests. To the American Medical Association, medical information on the computer is not the same as personal care from a physician. The risks of consumption of non-prescription drugs include failure to detect disease progression or the need for a change in dosage ${ }^{29}$.

Despite WHO supporting rational and responsible self-medication with effective and safe ${ }^{20}$ drugs, the lack of information available to the general public about possible risks and drug interactions occurs in much of the developing world. In many African and Latin American countries, there is no policy of overt disclosure about important aspects of OTC drugs, such as maximum allowed dosage and side effects ${ }^{25,28}$. Another fact is that these drugs can be sold in any quantity to the same patient, which is a serious situation for people taking medications with suicidal intentions, or even naively ${ }^{22}$.

According to the Argentinian Pharmaceutical Confederation (COFA), self-medication causes the death of approximately 700 people/year per 100,000 hospital admissions in the country, and the abuse of medicinal drugs is the second leading cause of poisoning addressed in Argentinian hospitals. In a recent survey, close to $82 \%$ of respondents in Buenos Aires and Córdoba reported taking OTC medicines, but more than half were unaware of their potential adverse effects 5 . In Argentina, both acetaminophen and herbal medicines are sold freely and without quantity limits per person.

In Mexico today, there is great need for actions to strengthen the regulation and supervision of pharmacies, and legislation that promotes the appropriate use of OTC medications. The purpose of providing these actions is to offer tools to the users of medicine so that they might make responsible decisions about their health, protecting themselves from the potential risks derived from self-consumption of medicinal drugs ${ }^{28}$.

In Brazil, a phenomenon deserving caution involves a list of 73 generic drugs, many OTC, available for free or with discounts of up to $90 \%$ to the public through the official People's Pharmacy program ${ }^{1}$. These pharmacies do not highlight the possible risks, side effects or drug interactions of these products. To report a problem, the Brazilian Ministry of Health provides the phone number 136, a type of ombudsman, as well as some reporting on the ANVISA website. The recent measure from the Brazilian official organ allows all pharmacies to market OTC medication in display racks away from the counter and without limits on quantities sold. Mitigating this, pharmacies are required to display posters with the following guidelines: "Drugs may cause unwanted effects. Avoid selfmedication. Inquire with the pharmacist "1,8.

However, according to the Federal Council of Medicine, this measure leads the population to self-medication and the irrational use of medicinal drugs, burdening the health system with the increase of preventable hospitalizations for drug intoxication, forming together with public opinion the idea that these drugs do not cause harm ${ }^{8}$.

Updated data available in Brazil through the National System of Pharmaceutical Poisoning Information (SINITOX) show that in 2010, 24,056 people suffered medicinal drug intoxication. Of these, $2.72 \%$ were due to self-medication. But the data does not report the medicines involved in the casuistry. At SINITOX, topics such as attempted suicide, medicinal drug abuse, misuse of medicines and self-medication are classified separately as independent situations. Together, these situations correspond to $45 \%$ of cases of drug intoxication ${ }^{10}$. Ideally, the data should be more specific and clear regarding the types of medications and the outcomes caused by them.

In a cross-sectional study in Campinas, São Paulo between 2008 and 2009 with 1,515 elderly, it was found that $9 \%$ of the sample had practiced self-medication. The most commonly used drugs were, in descending order: dipyrone, acetylsalicylic acid, diclofenac, Ginkgo biloba and acetaminophen ${ }^{19}$. Yet another cross-sectional study conducted in 2010, also in Brazil, with 789 college students, found an $86 \%$ prevalence of self-medication, of which the most commonly 
used drugs were, in descending order: acetaminophen, dipyrone, acetylsalicylic acid, herbal medicines and herbal teas $^{6}$. Among low-income adults in São Paulo, 27\% to 32\% had practiced self-medication ${ }^{24}$. In all these studies, selfmedication increased progressively with increased income.

In Australia, one prospective cohort study between 1992 and 2004 , evaluated 2,087 elderly and detected a prevalence of $35.5 \%$ of self-medication, and the drugs most used were vitamins and minerals, followed closely by acetaminophen ${ }^{12}$.

In Africa, a cross-sectional study in Assendabo, Ethiopia, with 1,257 people, found self-medication in $39 \%$ of the cases; and of these, $80.6 \%$ had no information on adverse reactions and other potential deleterious effects of the medications used. The authors of this study suggested as fundamental the application of regulations on the dispensing of medicines, as well as providing health education ${ }^{25}$.

\section{Acute medicinal liver failure}

Over the years, various drugs have been implicated in liver failure in several reports, but not all as OTC medicines. Of the medications restricted to prescription sale, valproic acid $^{3}$, isoniazid ${ }^{21}$, the clavulanate/amoxicillin combination ${ }^{27}$ and amiodarone ${ }^{2}$ stand out. The psychotropic drug "ecstasy" (3-Methoxy-4-methylamphetamine) is the second leading cause of fulminant hepatic failure in people under 25 years of age in Europe 4 . Conceptually, the use of "ecstasy" is not characterized as self-medication as it is not considered medicine.

Among the medicinal drugs used for self-medication and that are related to liver diseases, the painkiller acetaminophen and a few herbal medicines are deserving of mention. These are sold OTC in most countries (Figure 1). Acetaminophen, or $\mathrm{N}$-(4-hydroxyphenyl) ethanamide, is generally a safe drug when used within the recommended doses in previously healthy individuals. However, it has a narrow therapeutic index and is hepatotoxic dose-dependent.

\begin{tabular}{|c|c|}
\hline Medicines & Authors \\
\hline $\begin{array}{l}\text { Paracetamol/ } \\
\text { Acetaminophen }\end{array}$ & $\begin{array}{l}\text { Larson et al. (2005); Sass et al.(2005); } \\
\text { Dart et al.(2007); Bernal et al.(2010); } \\
\text { Rhodes et al.(2011). }\end{array}$ \\
\hline $\begin{array}{l}\text { Camellia sinensis (in } \\
\text { capsules) }\end{array}$ & $\begin{array}{c}\text { Gloro et al.(2005); Molinari et al.(2006); } \\
\text { García-Cortés et al.(2008); } \\
\text { Krishna et al.(2011) }\end{array}$ \\
\hline $\begin{array}{l}\text { Rhamnus purshianus and } \\
\text { isoflavones } \\
\text { (Fitosoja }{ }^{\circledR} \text { and Biosoja }{ }^{\circledR} \text { ) }\end{array}$ & García-Cortés et al.(2008) \\
\hline Conjugated Linoleic Acid & Nortadas et al.(2012) \\
\hline $\begin{array}{c}\text { Usnic acid (Somalyz }{ }^{\circledR} \text { and } \\
\left.\text { Lipolyz }{ }^{\circledR}\right)\end{array}$ & Krishna et al.(2011) \\
\hline
\end{tabular}

FIGURE 1 - Main substances related to self-medication and ALF

The risk of acetaminophen toxicity is considerably higher among the elderly, malnourished and chronic alcoholics ${ }^{7,14}$. The FDA allows the free sale of acetaminophen in pharmacies and supermarkets in dosages of $650 \mathrm{mg}$ per tablet, and without a limit on the amount of medication per individual ${ }^{26}$. A similar situation occurs in Brazil, with dosages of $500 \mathrm{mg}$ to $750 \mathrm{mg}$ per pill, also sold without restrictions regarding the amount per patient ${ }^{8}$.

Acute liver failure is generally diagnosed when the symptoms last for a maximum of 26 weeks in patients without pre-existing cirrhosis, mainly affecting young adults. Acetaminophen is still the leading cause of ALF in the USA as well as in most countries of Western Europe and Australia, but more than $50 \%$ of cases have unknown origin. In China, India, Pakistan and most of Southeast Asia, ALF is generally due to the hepatitis E virus. However, in Eastern European countries, the Amazon basin and Sub-Saharan Africa, ALF is related to hepatitis $B^{4}$. No official statistics, or even statistics from non-governmental organizations, were found regarding the incidence and cause of ALF in Latin American countries.

A multicenter prospective study in 22 transplant centers of the USA showed that acetaminophen caused $42 \%$ of the cases of ALF in that country. For this study, a toxic dose of acetaminophen was considered to be an intake greater than or equal to $4 \mathrm{~g} /$ day; however, $7 \%$ of those that had ALF ingested less than $4 \mathrm{~g} /$ day. Of all patients who had ALF due to acetaminophen, $65 \%$ survived without transplantation, $27 \%$ died without transplantation, and $8 \%$ underwent transplantation, of which $29 \%$ died within three weeks. Other interesting data from this study show that $44 \%$ used acetaminophen with suicidal intent. The authors suggest that these data do not represent the true incidence of ALF in the general population because many patients are not referred to transplant centers for lack of diagnosis, poor prognosis (elderly, people with cancer) or underreported cases $^{14}$.

A systematic review comparing retrospective and prospective studies in order to verify whether the use of therapeutic doses of acetaminophen causes ALF, concluded that in prospective studies there was a slight increase in serum levels of liver enzymes, but ALF and deaths were not found. Though, retrospective studies have shown liver enzyme levels beyond a higher elevation, $0.06 \%$ of deaths ${ }^{7}$. By analyzing these data, it appears that, at therapeutic doses and with rational use, acetaminophen is a safe drug, as mentioned above. The problem is precisely its irresponsible and irrational use, which was not the aim of the systematic review.

Another class of drugs that should be highlighted in relation to ALF is herbal remedies, or phytotherapics. In a large retrospective study conducted in Spain in 2006 with data collected since 1994 from the Spanish Registry of Hepatotoxicity, of 521 cases of severe liver injury, 2\% were due to natural medicines and dietary supplements, Camellia sinensis being the main player since it is used with the goal of weight loss. Most patients used this substance for an average period of 79 days and sought medical help because of jaundice. There were no deaths in this study ${ }^{11}$.

In Spain, the low incidence of ALF due to acetaminophen, unlike most Western countries, is due to the fact that it has controlled this drug's sales ${ }^{11}$. Currently, Spain, as well as France and the UK, limit the packet size and restrict the amount of acetaminophen purchased by each patient ${ }^{22,23}$. Still, in the UK, acetaminophen is responsible for approximately 500 deaths annually and causes $57 \%$ of cases of $\mathrm{ALF}^{4}$.

However, in relation to so-called natural medicines, despite the care of drug-monitoring agencies, it has been virtually impossible to control these substances, which are freely sold in pharmacies and natural dietary and health stores. Some factors that may contribute to the hepatotoxicity of natural remedies include failure to identify components of the product, selection of inappropriate parts of the plant, and contamination in the preparation or improper storage $\mathrm{e}^{11,17}$.

The obesity epidemic has promoted the growth of a sophisticated range of diet products, supplements and socalled natural medicines, most being unproven or having little scientific evidence ${ }^{13,17,18}$. Among reports on dietary and herbal medications causing ALF, deserving of mention are conjugate linoleic acid $^{18}$, usnic acid ${ }^{13}$ and green tea extract (Camellia sinensis $)^{17}$, all of which are used as diet remedies in pill form. Both in Spain and in France, the product "Exólise", a green tea extract in pill form, was removed from the market ${ }^{11,17}$.

In the USA, these substances are not regulated as drugs by the FDA, but as foods or dietary supplements ${ }^{26}$, favoring their consumption. Brazil also follows this guidance, and 
natural medicines are freely sold in pharmacies, supermarkets and health food stores.

Therefore, further studies are needed, without conflicts of interest, in order to verify the actual incidence of ALF in Latin America and its relationship with medicines and hepatitis.

\section{DISCUSSION}

ALF due to self-medication is a real possibility in many areas, including developed countries like the USA. The greatest problem detected is the irresponsible use of medicines by a portion of the population, the result of poor disclosure about risks, side effects and drug interactions. It is likely that an overt advertising campaign regarding such aspects of self-medication, along with a limitation on the amount of sales of these medicines to each patient, might help in controlling and reducing cases of drug poisoning, liver injury and acute liver failure. These authors suggest that the $\mathrm{WHO}$ and national medicine-monitoring agencies take such measures, intensifying the dissemination of medicinal awareness and the control of sales of self-medication.

\section{CONCLUSIONS}

Legislation and supervision disabled and information inaccessible to people, favors the emergence of cases of liver failure drug in many countries. In the list of released drugs that deserve more attention and care, are some herbal medicines used for the purpose of weight loss, and acetaminophen. It is recommended that institutes of health intensify supervision and better orient their populations on drug seemingly harmless, limiting the sale of products or requiring a prescription for release them.

\section{REFERENCES}

Bruno: No PT tem 32 referencias e no EN 29 !! verificar

Agência Nacional de Vigilância Sanitária [homepage na internet] Medicamentos. [acesso em 2012 dez 16]. Disponível em: http:// www.anvisa.org.br

Akbal E, Batgi H, Koçak E, Canatan T, Köklü S. Low-dose amiodaroneinduced fatal liver failure. Drug Chem Toxicol. 2013; 36(2): 261-2.

Antoniuk SA, Bruck I, Hönnicke LR, Martins LTF, Carreiro JE, Cat R. Insuficiência aguda hepática associada ao ácido valpróico na infância: relato de três casos. Arq. Neuro-Psiquiatr. [online]. 1996; 54(4): 652-54. Disponível em: http://dx.doi.org/10.1590/S0004282X1996000400015.

Bernal W, Auzinger G, Dhawan A, Wendon J. Acute liver failure. Lancet 2010; 376(9736): 190-201.

Confederación Farmacéutica Argentina [homepage na internet]. Automedicación. [acesso em 2013 jan 12]. Disponível em: http:// www.cofa.org.ar/?p=1718

Correa da Silva MG, Soares MC, Muccillo-Baisch AL. Self-medication in university students from the city of Rio Grande, Brazil. BMC Public Health. 2012 mai [acesso em 2012 set 16]; 12(1):339. Disponível em: http://www.biomedcentral.com/1471-2458/12/339

Dart RC, Bailey E. Does therapeutic use of acetaminophen cause acute liver failure? Pharmacotherapy 2007; 27(9):1219-30.

Exposição de medicamentos: Medida da ANVISA banaliza o consumo. Jornal Medicina/CFM. 2012 ago. n.211. p:9.

Fonseca-Neto, OCL. Falência hepática fulminante: etiologia, manejo e indicação para o transplante de fígado. ABCD Arq Bras Cir Dig. 2008; 21(4): 201-4.

Fundação Oswaldo Cruz [homepage na internet]. Sistema Nacional de Informações Tóxico-Farmacológicas. [acesso em 2013 jan 13] Disponível em: http://www.sinitox.icict.fiocruz.br

García-Cortés M, Borraz Y, Lucena MI, et al. Liver injury induced by "natural remedies": an analysis of cases submitted to the Spanish Liver Toxicity Registry. Rev Esp Enferm Dig. 2008; 100(11): 688-95.
Goh LY, Vitry AI, Semple SJ, Esterman A, Luszcz MA. Self-medication with over-the-counter drugs and complementary medications in South Australia's elderly population. BMC Complement Altern Med. 2009 nov [acesso em 2012 set 16]; 9:42. Disponível em: http://www. biomedcentral.com/1472-6882/9/42

Krishna YR, Mittal V, Grewal P, Fiel MI, Schiano T. Acute liver failure caused by 'fat burners' and dietary supplements: A case report and literature and literature review. Can J Gastroenterol. 2011; 25(3): 157-60.

Larson AM, Polson J, Fontana RJ, Davern TJ, Lalani E, Hynan LS et al. Acetaminophen-induced acute liver failure: Results of a United States multicenter, prospective study. Hepatology 2005; 42(6): 1364-72.

Larson AM. Diagnosis and management of acute liver failure. Curr Opin Gastroenterol. 2010; 26: 214-21.

Leake CD. The History of Self-Medication. Ann New York Acad Sci. 1965; 120(3): 815-822.

Molinari M, Watt KDS, Kruszyna T, Nelson R, Walsh M, Huang W et al. Acute liver failure induced by green tea extracts: Case report and review of the literature. Liver Transpl. 2006; 12: 1892-5.

Nortadas R, Barata J. Fulminant hepatitis during self-medication with conjugated linoleic acid. Ann Hepatol. 2012; 11(2): 265-7.

Oliveira MA, Francisco PMSB, Costa KS, Barros MBA. Self-medication in the elderly population of Campinas, São Paulo State, Brazil: prevalence and associated factors. Cad. Saúde Pública 2012 [acesso em 2012 set 10]; 28(2): 335-345 Disponível em: http://dx.doi. org/10.1590/S0102-311X2012000200012

Organização MundialdeSaúde[homepagenainternet].Medicamentos. [acesso em 2012 dez 16]. Disponível em: http://www.who.int/ medicines/en/index.html

Pereira RM, Tresoldi AT, Hessel G. Insuficiência hepática pelo uso de isoniazida: relato de caso. Arq. Gastroenterol. [online]. 2000; 37(1): 72-75. Disponível em: http://dx.doi.org/10.1590/S000428032000000100014.

Rhodes R, Aggarwal S, Schiano TD. Overdose with suicidal intent: Ethical considerations for liver transplant programs. Liver Transpl. 2011; 17(9): 1111-16.

Sass DA, Shakil AO. Fulminant hepatic failure. Liver Transpl. 2005; 11(6): 594-605.

Schmid B, Bernal R, Silva NN. Automedicação em adultos de baixa renda no município de São Paulo. Rev. Saúde Pública [periódico na internet].2010 dez [citado2013jul05];44(6):1039-45.Disponívelem: http://www.scielo.br/scielo.php?script=sci_arttext\&pid=S003489102010000600008\&Ing=pt.

Suleman S, Ketsela A, Mekonnen Z. Assessment of self-medication practices in Assendabo town, Jimma zone, southwestern Ethiopia. Res Social Adm Pharm. 2009; 5(1): 76-81.

U.S. Food and Drug Administration [homepage na internet]. Drugs. [acesso em 2013 jul 02]. Disponível em: http://www.accessdata.fda. gov/scripts/cder/drugsatfda/index.cfm

Vela JF, Moncasi PS, Redondo GS, Villalba PF, Algora IM. Insuficiencia hepática secundaria a hepatitis por amoxicilina-ácido clavulánico. An. Med. Interna (Madrid). [online]. 2002; 19(10); Cartas al director. Disponível em: http://dx.doi.org/10.4321/SO21271992002001000020.

Wirtz VJ, Dreser A, Leyva R. El debate sobre la automedicación. Salud Pública Méx. 2009 [acessoem2012set10];51(3):179-180.Disponível em: http://dx.doi.org/10.1590/S0036-36342009000300004

Woodward C. A move toward self-medication in the United States. Can Med Assoc J. 2012; 184(10): 1130-1. doi: 10.1503/cmaj.109-4220. 